\title{
Razvoj biskupske i prezbiterske službe u prvim stoljećima Crkve
}

\author{
Drago TUKARA* \\ UDK: 27-9-722.52 • Pregledni članak \\ Primljeno: 23. listopada 2017. • Prihvaćeno: 18. lipnja 2018.
}

${ }^{*}$ Doc. dr. sc. Drago

Tukara, Katolički bogoslovni fakultet

u Đakovu Sveučilišta

J. J. Strossmayera u

Osijeku,

P. Preradovića 17,

31400 Đakovo,

Hrvatska, drago. tukara@gmail.com

Sažetak: Članak na indirektan način dotiče Crkvu kao instituciju i organizaciju, dok na neposredan način detaljnije pristupa predstavljanju onih koji čine dio crkvene hijerarhije, a to su biskupi i prezbiteri. Da bi se što bolje predstavilo i razumjelo postojanje i poslanje biskupa i prezbitera, potrebno je bilo, barem ukratko, istaknuti samu narav Crkve. Autor članak dijeli na tri poglavlja. U prvom poglavlju predstavlja Crkvu koja je imala svoje korijene u Starom zavjetu, a svoju puninu i utemeljenje pronašla je u Osobi Isusa Krista. Ona je prisutna u Božjem naumu još od starozavjetnih vremena, još kada su je proroci u slikama najavljivali. U drugom poglavlju autor se bavi biskupskom službom u prvo doba Crkve. O tome što su rekli crkveni oci o biskupima, o njihovoj ulozi $i$ mjestu unutar prve Crkve te kako su ih definirali odredeni sabori ili sinode obraduje taj dio rada. Autor donosi osobna promišljanja i razumijevanje crkvenih otaca o biskupskoj službi, kao i određene kanone koji su nastali kao plod biskupskoga kolegijaliteta i jednodušnosti. Treće poglavlje govori o prezbiterima. Autor ponajprije predstavlja ulogu prezbitera u prvoj Crkvi, zatim naznačuje razvojni put od same terminologije pa do područja djelovanja u pojedinim trenutcima života Crkve. Prezbiter je stavljen u suodnos s biskupom, o njemu ovisi, ali s vremenom zbog novonastalih okolnosti on poprima određenu samostalnost unutar zajednice. Autor naglašava i važnost formacije i odgoja crkvenih službenika na teološkom i moralnom području.

Ključne riječi: Crkva, biskup, prezbiter, hijerarhija, crkvena zajednica. 


\section{Uvod}

Od samih početaka Crkva je imala svoje službenike: biskup, prezbiter, đakon. Oni su upravljali dogmatsko-teološko-liturgijskim životom vjernika, i to svaki na svome području, odnosno uzajamno i u jedinstvu. Današnje službe biskupa, svećenika i đakona po svom obliku i djelovanju dovoditi u gotovo identičan odnos s istima $\mathrm{s}$ početka Crkve bio bi djelomičan ili neuspio pokušaj. Takvom neuspjelom pokušaju doprinijela bi nejasna terminologija, različito pastoralno područje djelovanja, geografska udaljenost pojedinih crkava koje su imale ponekad i vlastite prakse, zatim utjecaj hereza, privatnih mišljenja i stavova o hijerarhiji Crkve te društveno politički život. Jedno je sigurno i gotovo identično, služba biskupa, kao i sve druge službe, od početka do danas ima svoj kontinuitet ili apostolsko nasljeđe u očuvanju evanđelja.

Riječ je o zahtjevnim i odgovornim službama, od Krista željenima, koje su ušle u treće tisućljeće i koje su, dakako, imale svoj razvojni put, ali nikad u bitnome. Bit im je nasljedna od apostola, vođena Petrovim nasljednikom, a sadržaj svoga djelovanja dobili su od Krista: naučavanje, posvećivanje i upravljanje. Govor o tim službama govor je i o Crkvi koja je promatrana u bitnim svojim oznakama kao povijesna, putujuća, jedna, sveta, katolička, apostolska. Za svoj hod kroz povijest i postojanje, sve do vječnosti, potreban joj je određeni ministerijalni ustroj.

O naravi Crkve, o zahtjevnosti i odgovornosti njezinih službenika govorit će i Drugi vatikanski sabor, koji će se rado i s mnogo ljubavi okrenuti prema izvorima i potražiti pouzdani odgovor te ga dati današnjemu svijetu, posebno u konstituciji Lumen gentium.

\section{Narav Crkve}

U mnogočemu Crkva u svojim početcima nije bila definirana, i u svome predstavljanju svijetu po sadržaju i poslanju i po svojim službenicima. Istina, svoju narav pronalazi u naumu Božjem, u starozavjetnom pretkazivanju budućih događaja preko određenih osoba i slika i u novozavjetnom ostvarenju i ustanovljenu preko želje i riječi Isusa Krista. Svoju narav i poslanje Crkva još jednom ističe preko, za nju, najznačajnijega događaja u dvadesetom stoljeću, Drugoga vatikanskoga sabora, kada se želi preispitati kakva je iznutra i izvana te na taj način ići od svoje nedefiniranosti prema definiranosti.

\subsection{Nastajanje Crkvene zajednice}

Prva kršćanska zajednica bila je uvjerena da je ona novi Izrael, narod novoga saveza i stoga nasljednica Božjih obećanja. Pavao razlikuje Izrael po tijelu i Izrael po duhu (Gal 4, 29; 1 Kor 10, 18). Oni koji vjeruju u Krista čine istinski Izrael, Božji Izrael, odnosno Crkvu. 
Kršćani su od početka drugoga stoljeća živjeli u svijesti da su Božji Izrael. Trifun, Židov, u dijalogu s Justinom otkriva upravo tu svijest kršćana kada postavlja pitanje Justinu: $\gg V i$ ste dakle Izrael? $\ll{ }^{1}$ Vladala je isto tako ideja da kršćani imaju pravo na Sveto pismo i da ga samo oni mogu ispravno tumačiti. Cijela je kršćanska zajednica puk Božji ili puk Kristov, gledano u širem smislu, ali postojalo je i drugo uže značenje: termin puk Božji odnosio se i na lokalnu zajednicu u odnosu prema njezinu biskupu ili na vjernike laike u odnosu prema zaređenom kleru. Još uže gledano, puk Božji odnosio se na župnu zajednicu.

Društveno-politička situacija u Rimskom Carstvu bila je podijeljena na plebejce i patricije, narod i staleže. Dakle postojali su oni koji su bili upravljačko tijelo ili skupina koja je donosila pravila i ostali narod kao članovi zajednice (plebs). Čini se vrlo vjerojatno da je kršćanska zajednica, prije Konstantina, pozajmila tu terminologiju jer je i sama dobivala izgled jedne nove društvene zajednice.

I Crkva je, kao narod od Boga pozvan, unutar sebe stvarala razliku s obzirom na staleške osobe (ordines, clerus), koje su obnašale službu upravljanja, i naroda (plebs), kojemu pripadaju svi kršteni koji nisu dio službe upravljanja, nazvani još i laici, vjernici. Kler i stalež mogu se promatrati kao sinonimi, ali pojam staleža može se primijeniti i na stalež biskupa i prezbitera.

\subsection{NASTAJANJE CRKVENE TERMinOlogije}

Kao što u početcima Crkve nije još postojalo ujednačeno odijevanje crkvenih službenika, tako nije bila ustaljena terminologija za iste. Tertulijan se obilno koristio pojmom svećenika za službenike koji su obašali neku službu. Za njega je biskup summus sacerdos i kler je različit od laika ${ }^{2}$. I Apostolska tradicija donosi razlikovanje među službenicima u posvetnoj molitvi pri ređenju biskupa: »Oče ti koji poznaješ srca, daj ovome sluzi kojeg si izabrao za episkopa, da napasa tvoje sveto stado, da poučava, na besprijekoran način i tebi u čast, da bude s najvećim svećeničkim dostojanstvom tebi na službu danju i noću (...) da ti prinosi darove svete Crkve, da ima po duhu velikoga svećenika moć otpuštati grijehe po tvojoj zapovijedi... $\ll^{3}$

Za Origena biskup je sacerdos u punom smislu riječi, dok je svećenik sacerdos nižega reda. ${ }^{4}$ Početkom trećega stoljeća termin sacerdos i summus sacerdos odnosio se na biskupa. Sacerdos je sinonim za episkopus, rijetko se kada odnosio na prezbitera, a

\footnotetext{
${ }^{1}$ JUSTIN, Razgovor s Trifunom, Split, 2011., br. 123, 7.

${ }^{2}$ Usp. TERTULIJAN, De baptismo, br. 17 (PL 17, 1188-1190).

${ }^{3}$ IPPOLITO DI ROMA, La tradizione apostolica, Rachele Tateo (ur.), Milano, 1995., br. 3.

${ }^{4}$ Usp. ORIGEN, Homilia XI in Exodum, br. 6 (PG 12, 380-381d).
} 
kada se odnosio na svećenika mislilo se na svećenika drugoga reda. Takva uporaba termina bila je i u četvrtom stoljeću, posebno na Istoku. To poistovjećivanje biskupa i svećenika pojmom sacerdos bilo je plod novonastale situacije u Crkvi: kako je brojem rasla kršćanska zajednica i kako se širila i na sela, prezbiteri su slavili euharistiju, poučavali i vodili narod, obavljajući tako sve poslove koji su dotada pripadali samo biskupu. Ta novonastala crkvena situacija zahtijevala je dakle da i prezbiteri obavljaju one poslove koji su do jučer pripadali samo biskupu, a samim time dovela neke mislioce, npr. Jeronima, do razmišljanja da je razlika između prezbitera i biskupa samo disciplinskoga, a ne strukturalnoga značenja.

Od petoga stoljeća pojam sacerdos isključivo se odnosi na prezbitera, dok se archiereus (nadsvećenik) odnosio na biskupa. Na zapadu se to dogodilo tek u sedmom stoljeću. $S$ vremenom su nastajale sve veće razlike između klera i vjerničke zajednice, a tomu su doprinijeli određeni propisi: kleričko odijevanje, zabrane sudjelovanja klera u određenim prigodama, crkveni celibat, uvođenje vanjskoga znakovlja kao što je tonzura, zabrana klericima da se bave određenim profesijama, zatim oprost od nekih državnih taksi, različiti privilegiji, zabrana raspoređivanja dobara prema svojoj volji, oporuka u korist Crkve... Ti elementi nisu samo činili klerike različitim od drugih, nego je sve više rasla tendencija odvajanja klera od zajednice, stvarala se bipolarnost. Unutar crkvene stvarnosti sve je više jačala hijerarhija. Biskup određuje koliko kojem kleriku nešto pripada od vjerničkoga priloga, već prema službi koju obavlja. U takvoj situaciji uvodi se razlika između vlasti stečene po sakramentu ređenja i jurisdikcijske vlasti, odnosno hijerarhije. Tako se stvara razlika među samim crkvenim službenicima. Sve je to nastajalo poslije jer u vrijeme crkvenih otaca biskup se uvijek povezivao s konkretnom zajednicom u kojoj je živio.

\section{Biskup u naravi Crkve}

U narav Crkve spada postojanje i djelovanje biskupske službe. Apostoli su imali svoje pomoćnike u službi kojima su povjerili misiju da nastave nakon njihove smrti. Prema svjedočanstvu Predaje to su bili biskupi, koji opet preko svojih nasljednika, sve do danas, iznose i čuvaju apostolsku predaju.

\subsection{BISKUP - POGLAVAR ZAJEDNICE}

Riječ biskup ${ }^{5}$ u početku je imala općenitije značenje, ali već na početku drugoga stoljeća sveti Ignacije Antiohijski svjedoči u svojim poslanicama o monarhijskom

\footnotetext{
${ }_{5}^{5}$ Termin biskup ili grčki episkopos pojam je kojega su preuzeli kršćani i njime opisivali djelatnost svojih službenika. Naziv episkopos novost je u kršćanskoj sredini i rado je prihvaćen, vjerojatno iz razloga da se izbjegne dotadašnja terminologija, odnosno da se stvori razlika s obzirom na starozavjetne termine: archiereus, hiereus, levites. Dakle težilo se prema stvaranju razlike između starozavjetnih
} 
ustrojstvu zajednice vjernika, a to znači da je uprava u zajednici sve više pripadala jednom službeniku - episkopu.

Taj apostolski otac piše: »Svi budite podložni biskupu kao Isus Krist Ocu i svećenstvu kao apostolima, a đakone poštujte kao Božju zapovijed: Neka nitko mimo biskupa ne čini ništa što se tiče Crkve. Neka se valjanom euharistijom smatra ona koja se vrši pod vodstvom biskupa ili onoga kome on dopusti. Gdje je biskup, ondje je i zajednica, kao i gdje je Krist Isus, ondje je i Katolička Crkva. Bez biskupa nije dopušteno ni krstiti ni slaviti bratsku gozbu, nego samo što on odobri, to je i Bogu milo, da sve što se čini bude sigurno i valjano. $\ll^{6} \mathrm{Iz}$ toga svjedočanstva vidi se da je biskup glava ili poglavar zajednice koja je već formirana. Ovdje su prisutne dvije činjenice: $s$ jedne strane biskup, a s druge strane zajednica. I za jednu i za drugu stvarnost u Crkvi se tražilo dogmatsko-teološko obrazloženje za njihovo postojanje. Za poznavanje problematike službe biskupa u prvoj Crkvi potrebno je dobro poznavati jezičnu strukturu određenih pojmova i postupni razvoj raznih imena za crkvene službenike sve do ustaljenih termina.

\subsection{BISKuP U BOŽJOJ ZAMISLI}

Rasprava o biskupskoj službi, bez obzira na to u kojem se povijesnom trenutku vodila, ujedno je rasprava o čuvanju i obrani katoličkoga nauka, bez ikakvih nakana da se nečije privatno promišljanje o tom pitanju nametne kao službeno. U tom smislu ni to što je pisao Ignacije Antiohijski ni u kojem slučaju ne bi se moglo shvatiti kao nešto privatno, štoviše, odzvanja kao stvarnost tadašnje Crkve. Ovdje je riječ o službi u zajednici, a ne o nekoj konkretnoj osobi. To znači da se stavlja naglasak na službu u zajednici koja svoje korijene i utemeljenje pronalazi u apostolima, odnosno u samoj zamisli Boga. Bog ga je izabrao; tko je s njim u zajedništvu, s Bogom je $\mathrm{u}$ zajedništvu, tko je s njim u zajedništvu, s cijelom Crkvom je u zajedništvu. Tomu u prilog ide i ono što zapisa Klement Rimski: »I naši su apostoli po Gospodinu Isusu Kristu znali da će biti prepirke oko biskupske službe. Zbog toga, dobro znajući što će se dogoditi, postaviše ranije spomenute i zatim zapovjediše da nakon njihove smrti njihovu službu preuzmu drugi prokušani muževi. «7

i novozavjetnih službenika. Episkopos je naziv koji označava djelatnost onih osoba koje su trajno nastanjene u zajednici i koje tu zajednicu nadgledaju. Ostalo je zamršeno pitanje najispravnije terminologije kojom se koristilo za službenike Crkve.

${ }^{6}$ IGNACIJE ANTIOHIJSKI, Pismo Smirnjanima, br. 8, 1-2, u: Apostolski oci I., I. Bodrožić (ur.), Split, 2010. (= Apostolski oci I.)

${ }^{7}$ KLEMENT RIMSKI, Pismo Korinćanima, br. 44, 1, u: Apostolski oci II., I. Bodrožić (ur.), Split, 2010. (= Apostolski oci II.) 


\subsection{BISKUP - ZNAK JEDINSTVA U LJUBAVI}

Poslanice Ignacija Antiohijskoga govore o volji Kristovoj kad je u pitanju monarhijsko ustrojstvo crkvenih zajednica ili općina u postapostolsko doba.

U pismu Efežanima ${ }^{8}$ kaže: $\gg U$ ime Božje vašu sam mnogobrojnu zajednicu primio u Onezimu, mužu neizrecive ljubavi i vašemu biskupu u tijelu. Molim vas ljubite ga u Isusu Kristu i svi mu budite nalik. Blagoslovljen onaj koji se udostojao udijeliti vam svoju milost - a dostojni ste je - da imate takva biskupa.« Malo dalje piše: »No, budući da mi ljubav ne da pred vama šutjeti, pretekoh vas poticajem da budete suglasni s voljom Božjom. Ta i Krist Isus, naš nerazdjeljivi život, volja je Očeva, upravo kao što su i biskupi, postavljeni sve do krajeva svijeta, po volji Isusa Krista. $\ll{ }^{9}$ Ili: $\gg$ Stoga da bismo bili Bogu odani, nastojmo ne protiviti se biskupu $\ll{ }^{10}$, te nastavlja: »Pa što više netko opaža kako je biskup šutljiv, neka ga to više poštuje; jer koga god glava obitelji pošalje da upravlja njegovim kućanstvom, trebamo ga prihvatiti kao samoga onoga tko ga šalje. Biskupa, dakle valja častiti kao samoga Gospodina. ${ }^{11}$

U pismu Magnežanima napominje da vjernici trebaju, poštujući vlast Boga, poštovati samoga biskupa ${ }^{12}$ te poziva da se sve čini u Božjoj slozi uz predsjedanje bisku$\mathrm{pa}^{13}$ kao da se ništa ne čini bez biskupa ${ }^{14}$.

A u pismu Tralijanima naučava da je biskup slika $\mathrm{Oca}^{15}$, a bez svećenika i biskupa nema govora o Crkvi. Vjernike u Filadelfiji poučava ovako: »Znam da je službu ravnanja zajednicom biskup primio ne za sebe, ni za ljude, ni za ispraznu slavu, već u ljubavi Oca i Gospodina Isusa Krista. $\ll^{16}$

Ta su Ignacijeva pisma dovoljan dokaz o bitnom i formalnom ustrojstvu crkvene zajednice, a to upućuje na shvaćanje i naučavanje o postupnom razvoju monarhijskoga ustrojstva zajednice i cijele Crkve. A svoje porijeklo ima u apostolima i njihovim nasljednicima. Ignacije nas izvještava o samo jednom obliku crkvenoga

\footnotetext{
${ }^{8}$ IGNACIJE ANTIOHIJSKI, Pismo Efežanima, br. 1, 3, u: Apostolski oci I.

${ }^{9}$ Isto, br. 3, 2.

${ }^{10}$ Isto, br. $5,1$.

${ }^{11}$ Isto, br. 6, 1.

${ }^{12}$ ISTI, Pismo Magnežanima, br. 3, 1, u: Apostolski oci I.

${ }^{13}$ Isto, br. 6, 1.

${ }^{14}$ Isto, br. 7, 1. Istu misao navodi u Pismu Smirnjanima, br. 8, 1.

${ }^{15}$ ISTI, Pismo Tralijanima, br. 3, 1, u: Apostolski oci I., te u: ISTI, Pismo Polikarpu, br. 6, 1, u: Apostolski oci I.

${ }^{16}$ ISTI, Pismo Filadelfijanima, br. 1, 1, u : Apostolski oci I.
} 
ustrojstva, o monarhijskom. Tomu ide u prilog činjenica da protivnici u prvoj Crkvi, odnosno heretici, nisu nigdje u sporovima navodili da apostoli nisu postavljali biskupe. Iako je bilo razdora u prvim crkvenim zajednicama, nema nigdje traga da je bila neujednačena praksa po pitanju postavljanja nekoga za biskupa. To vodi zaključivanju da je ipak u Crkvi postojala ujednačena praksa; od početka, od apostola, nije se događala promjena ni bitan preokret crkvenoga ustroja uzrokovan bilo kakvim osobnim prepirkama ili tendencijama ${ }^{17}$.

Valja imati na umu riječi koje Pavao upućuje Timoteju: »Timoteju, čuvaj što ti je predano, kloni se profanih novotarija, ispraznih riječi i prepiranja lažno nazvane znanosti...« (usp. 1 Tim 6, 20) Pavao upozorava Timoteja da postoje oprečni stavovi po pitanju nasljedstva stečenoga sadržaja vjere ili tradicije općenito. Crkva, vođena takvim apostolskim uputama, uvijek je imala jasan stav i po pitanju biskupske službe. Dogma i kanonsko pravo kada istražuju hijerarhiju prve Crkve, odnosno pitanje postanka i razvoja biskupske službe, uvijek se osvrću na ono što povijest kao znanost istražuje. ${ }^{18}$

${ }^{17}$ Usp. I. P. BOCK, Je li postojala razlika među episkopima i prezbiterima već u prvom stoljeću?, u: Bogoslovska smotra 11(1923.)2, 151-181. Autor ovdje iznosi stav sv. Jeronima po pitanju monarhijskoga ustrojstva Crkve. Jeronim navodi raskole unutar zajednice koji su doveli do toga da su prezbiteri među sobom izabrali jednoga prezbitera i postavili ga na uzvišeniji položaj i nazvali ga biskupom; kao kad vojska izabire među sobom vojskovođu ili kao kad đakoni među sobom biraju arhiđakone. Tu vlast nisu dali apostoli ili njihovi nasljednici, nego sam Krist. Iako Jeronim ima oprečne stavove o biskupima, ipak se može zaključiti da ne niječe u potpunosti božansko porijeklo monarhijskoga ustrojstva crkvenih zajednica. U njegovo vrijeme bilo je arijanaca koji su držali da nema razlike između biskupa i prezbitera. Jeronim je upao u oprečnost zato što je poistovjećivao pojam episkopos i pojam presbyteros zaboravljajući na razvoj samih pojmova. Autor spominje da Jeronim u nekim drugim pismima napada one koji izjednačavaju đakona s prezbiterom, ukazujući na razliku između đakona, prezbitera i episkopa (usp. isto, 162-164.). O toj tezi ili problematici može se vidjeti i u: M. MANDAC, Jeronim. Tumačenje Pavlovih poslanica. Tumačenje Poslanice Titu, br. 1, 5, Makarska, 1998.

${ }^{18}$ Posebno su protestantski krugovi naglašavali nepremostivi jaz između Isusa i apostola te između apostola i njihovih nasljednika, čime se željelo istaknuti da postoji diskontinuitet crkvene hijerarhije. Katolička Crkva prihvaća povijesni razvoj episkopata i hijerarhije, ali samo na vlastitom području, odnosno $\mathrm{u}$ istoj dogmi, $\mathrm{u}$ istom smislu i $\mathrm{u}$ istoj misli. To znači da biskupska vlast ostaje ista dogma, isti smisao i istoga razmišljanja, bez diskontinuiteta. (Usp. I. P. BOCK, Je li postojala razlika među episkopima i prezbiterima već u prvom stoljeću?, 180-182.) Korisni radovi o tome: N. IKIĆ, Petrovska služba. Stijena jedinstva i kamen spoticanja. Povijesno-teološki, biblijsko-dogmatski i ekumenski pogledi, Zagreb, 2015.; T. IVANČIĆ, Stav istočnih otaca prema Rimskoj stolici, u: Bogoslovska smotra 48(1979.)3-4, 208-217. 


\subsection{BISKUP - RAZLIČIT OD DRUGIH}

Koncil u Sardici 343./344. godine zabranio je pridruživanje biskupskom staležu prije nego što osoba prethodno primi druge staleže, to znači da je trebalo proći određeno razdoblje između primanja jednoga i drugoga staleža kako bi se taj crkveni čovjek mogao pripremiti za primanje službe. To je vjerojatno posljedica promatranja situacije koja je vladala u državnim institucijama po pitanju stjecanja karijere. Tako se stvarao jedan tijek, put ili karijera (cursus) koja je postajala progresivno uzdizanje prema višemu stupnju, a to se smatralo čašću, dostojanstvom koje ima svoju snagu u rimskom pravu. Sveti Augustin rekao je za biskupe i prezbitere da su oni dostojanstvenici, časnici ${ }^{19}$. Nije riječ samo o terminološkoj razlici, nego od vremena cara Konstantina pa nadalje postoji razlika između puka (plebs) i staleža (ordo), koji su primili oblik i ponašanje iz civilnoga društva. Biskupi su na primjer primali insignije, palij i obuću, ali su nastajale i nove insignije ne samo za liturgijsku uporabu nego i da bi se u svagdanjem životu po odjeći razlikovali od ostalih vjernika. Sveti Ambrozije potiče kler da oblači običnu odjeću, a ne s upadljivim bojama ${ }^{20}$ ako još ne postoji zasebna odjeća. Nešto kasnije papa Celestin pisat će biskupima u Galiji da se oni ne trebaju razlikovati od drugih po odjeći, nego po nauku. ${ }^{21}$ Tendencija da se određene osobe jednoobrazno oblače povlači za sobom pitanje njihova sociološkoga određenja ${ }^{22}$.

\subsection{IZBOR BISKUPA}

Ne postoji neka točno propisana procedura izbora za biskupa, ali postojalo je predstavljanje kandidata lokalnom kleru i vjernicima ili izbor među trojicom kandidata koje su predložili najbliži svećenici. Sudjelovanje laika u izboru biskupa sve se više smanjuje prema kraju petoga stoljeća, zapravo, vrlo je teško steći uvid koliko

\footnotetext{
${ }^{19}$ AUGUSTIN, Enarratio in Psalmum, XVI, 5: »In ecclesia istae (episcopus et presbyter) sunt dignitates $\ll$ (PL 36, 1968).

${ }^{20}$ Usp. AMBROGIO, I doveri, I, 1, 82, u: Opera omnia di sant'Ambrogio, G. Banterle (ur.), Roma, 1977., 73-74.

${ }^{21}$ Usp. CELESTIN, Epistula 4, 1, 2 (PL 50, 429-431).

${ }^{22}$ Kao što se težilo ujednačenom oblačenju službenika Crkve, tako se težilo i prema ujednačenoj terminologiji. Do drugoga stoljeća ne postoji termin sacerdos koji bi se odnosio na nekoga službenika. Prva Crkva radije se koristila terminologijom za svoje službenike: episkopus, presbyter, iguman, poglavar, đakon. Vjerojatno je to bilo iz razloga što se u poganskom i židovskom svijetu pojam svećenika odnosio na određenu kastu ili obitelj kojoj pripada, a službu obavlja kao posrednik između božanstva i ljudi. Naime u kršćanstvu je svećenik izabran među svim vjernicima i ima ulogu bdijenja (episcopè), nadgledanja naroda Božjega, poučavanja i opsluživanja sakramenata. Kršćanski službenik nije svet jer je cijeli narod svet; za kršćane toga vremena ne postoji sveto mjesto, sveta osoba, sveto vrijeme, osim onoga liturgijskoga, jer svi su sveti, izabrani i pozvani u Crkvu.
} 
efektivno narod sudjeluje u izboru. Teško je precizirati, ali u petom stoljeću već je isključen narod iz hijerarhije, čija je uloga osigurana obvezom prisutnosti bližih biskupa na samoj posveti te obvezom metropolitove potvrde. Činjenica je da praksa posvuda nije bila ujednačena i ne treba čuditi ako je postojala kakva praksa sasvim različita od propisa sabora u Niceji.

Bilo je prisutno duboko uvjerenje da je biskupa izabrao Bog, koji je temelj njegova autoriteta. Zapravo, zajednica je bila ona koja je predložila kandidata za biskupa, makar i protiv njegove volje. $S$ početka Crkve poznate su mnoge osobe koje, nakon što su izabrane, nisu prihvaćale službu jer su u načelu izbjegavali crkvena zaduženja. ${ }^{23}$ Imamo svjedočanstvo o izboru biskupa i đakona: »Izaberite, dakle, sebi biskupe i đakone dostojne Gospodina, muževe krotke i nepohlepne za novcem, istinoljubive i prokušane; i oni vam vrše proročku i učiteljsku službu. $\ll^{24}$ Hipolit Rimski isto tako piše da biskup treba biti zaređen nakon što ga je narod izabrao kao besprijekornoga. Nakon što je postignuta jednodušnost svih, neka se nedjeljom okupi narod, zbor svećenika i biskupa... ${ }^{25}$ Ciprijan donosi još više pojedinosti: » Što se toga tiče treba brižno poštivati božansku tradiciju i apostolsku praksu; tradicija i praksa koje su kod nas nalaze se gotovo u svim provincijama. Kako bi se započela zakonska procedura po pitanju ređenja trebaju biti u zajednici gdje se obavlja izbor nazočni i obližnji biskupi koji pripadaju istoj provinciji. Izbor za biskupa se obavlja u zajednici. Narod doista poznaje život svakog pojedinog i zna procijeniti njihovo ponašanje živeći zajedno. ${ }^{26}$ Uloga naroda pri izboru biskupa jest više-manje važna, kako će reći jedan od pastira prve Crkve: »Onaj tko će biti određen za zajednicu morat će biti od svih i izabran. $\ll^{27}$

Što se tiče izbora osobe za biskupsku službu, on je imao svoj razvoj. Za latinske zemlje ostat će na snazi, pa i kroz srednji vijek, barem teoretski, da biskup bude izabran uz suglasnost naroda, laika i zbora biskupa cijele provincije, napose metropolita. Događale su se promjene, npr. Koncil u Arlesu 452. godine propisao je da kler i narod pripadajućega mjesta izaberu jednoga od triju kandidata koje su predložili

${ }^{23}$ Grgur Nazijanski, Ivan Zlatousti, Grgur Veliki... međutim danas se traži potpuna sloboda izabranoga na pristanak i prihvaćanje.

${ }^{24}$ Didachè, br. 25, 1, u: Apostolski oci II.

${ }^{25}$ Usp. IPPOLITO DI ROMA, La tradizione apostolica, 2.

${ }^{26}$ CIPRIJAN, Epistula 67, 5, 1, u: W. von HARTEL (ur.), Corpus Scriptorum Ecclesiasticorum Latinorum (= CSEL), III/2, Wien, 1871., 739.-740. U tom citatu nije poznato koja bi, konačno, bila uloga naroda, lokalnoga klera i obližnjih biskupa, međutim poznato nam je da je u rimskoj Crkvi uloga naroda, okupljenoga klera i obližnjih biskupa bila važna, o čemu se može vidjeti u M. POIRIER, Vescovo, clero e laici in una comunità cristiana nel III secolo negli scritti di san Cipriano, u: Rivista di Storia e Letteratura Religiosa 9(1973.), 17-36.

${ }^{27}$ LEON VELIKI, Epistula 10, 6 (PL 54, 634). 
susjedni biskupi. I na Istoku je narod imao važnu ulogu pri izboru biskupa, premda je sabor u Laodiceji 363. godine nastojao isključiti bučnost svjetine, koja je imala odlučujuću ulogu u nekim slučajevima kao što je izbor Ivana Zlatoustoga ${ }^{28}$. Negdje u petom stoljeću metropolit je izabrao jednoga među trima kandidatima koje je predložio kler, članovi mjesnoga senata, ugledni građani... Konačna norma došla je na Drugom nicejskom saboru 787. godine u trećem kanonu. Izbor je pridržan samo biskupima, odnosno bilo koji izbor za klerički stalež koji bi išao preko državnih vlasti nije valjan. Još je sabor u Niceji $325 .{ }^{29}$ godine u osmom kanonu propisao da u jednom gradu može biti samo jedan biskup, međutim događale su se iznimke na području afričke Crkve. Naime nakon što je Rimsko Carstvo ušlo u određenu fazu nestabilnosti i nereda, nastojalo se vratiti društvenu i političku sigurnost, pa su se za biskupe predlagale osobe koje bi mogle doprinijeti potrebnom miru i stabilnosti, bez obzira na propisana pravila o izboru. Za praksu, da se izabire osoba za biskupa koja će doprinijeti stabilnosti i miru u carstvu, bili su posebno zainteresirani carevi. Tako se događalo da su neki biskupi još za života izabrali svoga nasljednika, koji, doduše, još nije bio posvećen, kako bi se izbjegla kasnija mogućnost razdora i nemira u zajednici ${ }^{30}$.

Biskup je mogao biti izabran iz redova laika, ali ta praksa već od četvrtoga stoljeća prestaje jer se odlukom koncila u Sardici 343. godine navodi da biskup može biti izabran ili iz reda lektora ili đakona ili prezbitera. Budući da je biskup središte života kršćanske zajednice, bilo je potrebno sagledavati cijeli njegov život i zasluge prije posvećenja. Tako biskup Ciprijan piše svojim đakonima, svećenicima i cijeloj vjer-

\footnotetext{
${ }^{28}$ Usp. SOKRAT, Historia ecclesiastica, 6, 2 (PG 6, 662-664); vidi: http://www.newadvent.org/ fathers/2601.htm (18. 10. 2017.).

${ }^{29} \mathrm{Na}$ ovom koncilu Crkva je po prvi puta tražila norme s univerzalnim značenjem za čitavu njezinu strukturu. Ovdje želimo istaknuti samo one norme koje se tiču biskupske služe ali za čitavu Crkvu. Četvrti kanon se odnosi na potreban broj biskupa da bi se netko posvetio za novog biskupa: potrebno je da budu svi biskupi iz provincije, ali ako je to nemoguće, onda barem tri biskupa s pristankom onih koji su odsutni. Metropoliti je pripadala ovlast posvete. Crkva time započinje tražiti ovjerovljenje izabranoga. Šesti kanon govori o prvenstvu nekih sjedišta i o nemogućnosti da netko bude zaređen za biskupa bez pristanka metropolite. Ovaj kanon izražava smisao četvrtoga kanona. Ovdje se potvrđuje privilegij biskupa Aleksandrije, Rima i Antiohije. Očito je da je postojeći politički model utjecao i na crkvenu organizaciju. Kanon sedmi daje veliku prednost jeruzalemskom biskupu u prigodi otvaranja sinode, vjerojatno iz sentimentalnih razloga prema Jeruzalemu kao majci crkava, međutim politika će utjecati na promjenu na tom području i usmjeriti prema drugim sjedištima. Usp. www.documentacatholicaomnia.eu (10.10.2017.)

${ }^{30}$ Usp. POSSIDIO, Vita di Agostino, br. 8, u: Collana di testi patristici, M. Simonetti (ur.), Roma, 1977. Biskup Valerije piše pismo biskupu u Kartagu u kojem moli da, radi svoga zdravlja i starosti, može Augustina imati za nasljednika u Hiponu. Već je gore rečeno da praksa po tom pitanju bila drugačija.
} 
ničkoj zajednici da ih želi konzultirati i vrjednovati njihovo zajedničko mišljenje o ponašanju i zaslugama svakoga pojedinoga kandidata ${ }^{31}$.

Od četvrtoga stoljeća bili su uvjeti da netko ne može biti klerik ili biskup, odnosno navođene su zapreke. Sama Crkva nije dopuštala te službe osobama koje su uključene u javne zabave, državnim službenicima, vojnicima koji su kršteni prije vojničke službe, upraviteljima tuđih materijalnih dobara prije nego su položili račune svome gospodaru, robovima i robovima slobodnjacima jer nisu uživali potpunu slobodu. I država je zabranjivala određenim kategorijama građana ulazak u klerički stalež: pekarima, trgovcima, državnim službenicima, državnim savjetnicima i njihovim članovima obitelji. Razlog tomu jest bogaćenje Crkve koja bi stečenim novcem pomagala siromašne i podređene građane, čime bi slabila moć države. No ipak se rijetko događalo da se iz viših društvenih klasa tadašnjega vremena ulazilo i u crkvene službe. Nisu postajali biskupima osobe iz visoke aristokracije ni iz nižih klasa. Biti biskup bio jedan od načina da se »zauvijek oslobode javnih (državnih) službi ${ }^{32}$ koje su prije stekli. Oslobađanje od javnih službi, koje je uveo Konstantin, a poslije nastavili i njegovi nasljednici, odnosilo se i na niže crkvene staleže.

U prvoj Crkvi bilo je potrebno ograničiti broj dijeceza i biskupa. Sabor u Kalcedonu u kan. 17. dopustio je osnivanje nove dijeceze samo u jednom novom gradu. Gledano geografski, u petom stoljeću postojale su mnoge dijeceze, npr. na saboru u Kartagi bilo je 430 biskupa, katolika i donatista. U sjevernom dijelu Italije, u Galiji, Španjolskoj bilo je mnogo manje dijeceza. I ta činjenica govori da je prva Crkva u svom krilu imala doista velik broj službenika i velik broj mjesta u kojima su ti službenici djelovali.

Što se tiče duhovne, pastoralne ili teološke priprave kandidata za biskupsku službu, nije postojala službena ili sustavna izobrazba. Budući da se događalo da pojedini crkveni službenici nisu u svom djelovanju pokazivali određenu izobrazbu i prihvatljivo ponašanje, Crkva je sve više zahtijevala da kandidati za crkvenu službu prođu određene provjere (skrutinije) kako bi se stekla sigurnost u njihovu pravovjernost i moralno ponašanje. Nisu postojale posebne škole za to, nego se učilo na liturgijskim slavljima, $\mathrm{u}$ familijarnosti s nekim biskupom ili svećenikom, osobni trudom i vježbom. ${ }^{33}$

${ }^{31}$ Usp. CIPRIANO, Lettera 38, 1, u: Scrittori cristiani dell'Africa romana. Lettere 1-50, C. Moreschini (ur.), Roma, 2006.

${ }^{32}$ EUZEBIJE CEZAREJSKI, Crkvena povijest, 10, 7, 2, M. Mandac (ur.), Split, 2004.

${ }^{33}$ Sveti Jeronim piše Nepocijanu, mladom svećeniku i monahu: »Znam da si od svog ujaka, blaženog Heliodora, koji je sada Isukrstov veliki svećenik, naučio, a i svaki dan da se učiš onome što je sveto; pa jošte u njegovu življenju da imaš ugled kreposti. Ali primi i moju pouku, ma kakova bila, i ovu knjižicu sjedini s knjižicom što sam njemu pisao; i kad te ona uputi u monaštvu, ova nek te nauči da budeš savršen čovjek crkovni«, JERONIM, Pismo Nepocijanu svećeniku, br. 52, 4, u: ISTI, Izabrane poslanice, V. Rismondo (ur.), Split, 1990., 


\subsection{NAČELO JEDNOGA BISKUPA}

Načelo jednoga biskupa u jednom gradu uspostavljeno je već u trećem stoljeću. To potvrđuje jedno pismo Kornelija biskupu Ciprijanu. Riječ je o ispovijesti vjere koju su pred Kornelijem položili neki koji su se vratili iz Novacijanove hereze. Kornelije u pismu donosi njihovu ispovijest: $\gg$ Znamo da je Kornelije izabran za biskupa svete Crkve katoličke od Boga svemogućega i od Krista našega Gospodina. Dopuštamo da smo pogriješili. Bili smo žrtve jedne prijevare. Zavedeni smo lukavošću i brbljavošću koja zavodi. Naime, iako bi se moglo činiti da smo, ako možemo tako reći, u zajedništvu s čovjekom heretikom i šizmatikom, ipak je naše srce iskreno i ostalo je uvijek u Crkvi. Ne ignoriramo da je samo jedan Bog Gospodin svemogući, da je samo jedan Krist Gospodin kojeg ispovijedamo, da je samo je jedan Duh Sveti, i da treba biti samo jedan biskup u Crkvi katoličkoj. $\ll^{34}$

Biskup je odgovoran za ređenja, za pripuštanje novih članova u zajednicu, za ekskomunikaciju i ponovno izmirenje, za liturgijski život, za upravljanje materijalnim dobrima. Jednom riječju, biskup je glava i autokrat Crkve.

Načelo jednoga biskupa stupilo je na snagu u Niceji 325. godine, kanon 8., koji se odnosi na takozvane katare. Sljedbenici Novacijanove šizme, ujedinjeni s Novatom protiv Ciprijana, dali su početke jednoj paralelnoj rigorističkoj crkvi. U kanonu se utvrđuje da mogu ponovno biti pripušteni u Crkvu katoličku i da klerici mogu ostati među klerom uz prethodno polaganje ruku i pisanu izjavu vjernosti Crkvi. Ako je od njih već jedan biskup, neka se smatra svećenikom; ali titularni biskup može ga pridružiti sebi ili osigurati mu položaj subiskupa (biskup za selo). Seoski biskup ovisio je o gradskom, bio je nižega ranga, nije mogao rediti prezbitere i đakone bez dopuštenja biskupa iz grada. Tako je bilo od početka trećega stoljeća, a od četvrtoga stoljeća propisi ograničavaju broj takvih biskupa i umanjuju njihove ovlasti.

U svakom slučaju, načelo je jasno: ne mogu biti dva biskupa u jednom mjestu (gra$\mathrm{du}$ ). Jedinstvo biskupa osigurava jedinstvo vjere, nadasve obranu nicejske vjere. Još prije je tezu o jednom biskupu spominjao sv. Ciprijan: »Biskupstvo je jedno. Pojedinac na njemu ima dio jer ima sve. Crkva je jedna. $\ll^{35}$

U petom stoljeću došlo je do osporavanja ili nemogućnosti njegove primjene zbog dviju činjenica: broj vjernika povećavao se, isto tako ustanova novih crkava i oratorija, bilo u gradu ili selu. To vodi prema decentralizaciji. S druge strane susreće se teološko osporavanje razlike između biskupskoga i prezbiterskoga ređenja. Takvo

\footnotetext{
${ }^{34}$ CORNELIUS, Cypriano fratri 49, br. 2, 1, u: Scrittori cristiani dell'Africa romana, 323.; usp. H. DENZINGER, P. HÜNERMANN (ur.), Zbirka sažetaka vjerovanja, definicija i izjava o vjeri $i$ ćudoređu, Đakovo, 2002. (= DH), br. 108.

${ }^{35}$ CIPRIJAN, Jedinstvo Crkve, br. 5, M. Mandac (ur.), Makarska, 1987.
} 
osporavanje možemo naći kod Jeronima i Ambrozijastera. U poslanici 125. Jeronim piše Rustiku o prezbiterima koji su podređeni biskupima koji su autokrati. Jeronim zastupa jednakost dvaju stupnjeva, osim u nekim funkcijama, kao što je ređenje prezbitera. Jeronim piše svećeniku Nepocijanu o uzajamnom poštovanju biskupa i svećenika: »Budi podložan svome biskupu, i priznaj ga za oca duše svoje. Sinovima se pristoji štovati, a slugama bojati se... Ja hoću ovo reći: neka znaju biskupi da su svećenici, a ne gospodari: neka časte crkvene ljude kao takve, da crkveni ljudi poštuju njih kao biskupe. Lijepa je ona riječ govornika Domicija: 'Zašto ću ja tebe držati za kolovođu kad ti mene ne držiš za senatora?' Što bijahu Aron i sinovi mu, znajmo da su to biskupi svećenici. Jedan je Gospodin, jedna je Crkva, jedna treba biti i služba ...Vrlo je loš običaj u nekim crkvama da svećenici šute, i pred biskupima ne propovijedaju, kao da su biskupi zavidni, ili da se ne udostoje slušati. ${ }^{36}$

Pretpostavljamo da je riječ o liturgijskom slavlju u kojem svećenik ne propovijeda, nego to čini biskup, odnosno ukazuje na razliku službe jednoga i drugoga, iako se čini da je Jeronimova namjera izjednačavanje službe svećenika i biskupa. Naime poznato je da je u Jeronimovo vrijeme u Rimu bilo nekoliko đakona koji su se ponašali i držali većima od prezbitera, odnosno pridavali su si svećeničke ovlasti. ${ }^{37}$ Njihovo držanje Jeronim kritizira tako da upozorava đakona Sabinijana na njegovo ponašanje i u drugim situacijama: »Novca imaš dosta, ne bije te nikakva ljuta nesreća, i ne zaslužuješ biti ukoren s ljudima koji nisu, kao ti što si, nerazumne životinje. Zato si se osilio, i haljine su tvoje gizdavost; pa ne misleći da ćeš umrijeti, kao od debele slanine i nekakve masti, rigaš smrtonosne riječi; i nakon što izdovoljiš putenost, nikad se ne mučiš pokorom. Puštaš se na volju svoga srca; i da nisi sam koji si zašao s pravoga puta, izmišljaš na sluge Božje što se ne smije ni izustiti ... ${ }^{38}$ Time želi uzdići prezbitere na više dostojanstvo i staviti ih uz bok biskupima. Na drugom mjestu Jeronim piše Sabinijanu: Jeronimu je bila poznata praksa u Rimu da su đakoni za vrijeme liturgije sjedili, dok su prezbiteri stajali. Vjerojatno potaknut time, piše iz Betlehema tu pobudnicu na pokoru Sabinijanu i time upozorava na ovlasti đakona, i nije u tome sam. Naime i koncili su zabranjivali đakonima slaviti euharistiju i podjeljivati pričest svećenicima. ${ }^{39}$ Govoriti o đakonima ujedno i znači govoriti o hijerarhijskom ustroju unutar Crkve, odnosno naglasiti ono što je još sveti Ignacije Antiohijski posvjedočio o trostrukoj podjeli službenika. Za Ignacija su đakoni na trećem mjestu, podređeni prezbiterima i biskupima. A što se tiče udjela u liturgiji,

\footnotetext{
${ }^{36}$ JERONIM, Pismo Nepocijanu svećeniku, br. 52, 7.

${ }^{37}$ Usp. ISTI, Ad Evangelum, br. 146 (PL 22, 1192-1195).

${ }^{38}$ Usp. ISTI, Pobudnica na pokoru Sabinijanu, 147, 2, u: ISTI, Izabrane poslanice, V. Rismondo (ur.) Split, 1990.

${ }^{39}$ Usp. ISTI, Ad Sabinianum 147, 2 (PL 22, 1196-1197).
} 
đakoni nisu sudjelovali u lomljenju kruha i prinošenju kaleža, pomagali su samo biskupima, ali su zaslužili određeno poštovanje vjernika.

Čini se da je to važna činjenica za kasniji razvoj nauke o sakramentalnom karakteru biskupske službe, a pitanje će ponajbolje razriješiti Drugi vatikanski sabor.

\subsection{KANONSKA POTVRDA BISKUPSKE SLUŽBE}

Kanonski propis koji se odnosi na upravitelja zajednice pojavljuje se na Nicejskom koncilu 325. godine, a utvrđuje sljedeće: biskupa trebaju biti posvetiti svi biskupi provincije, a ako je to teško izvedivo, onda barem tri biskupa sa suglasnošću odsutnih biskupa u pisanom obliku. Potvrda izbora novoga biskupa daje se metropolitu. Nicejski sabor propisuje u kan. 5. da biskup treba održati dvije sinode na godinu, jednu prije korizme, a drugu na jesen. Razlog su tomu izopćeni iz jedne crkvene zajednice (iz Crkve) i pitanje njihova primanja u drugu zajednicu. Takvi ne mogu biti primljeni u drugu crkvenu zajednicu (biskupiju). I da bi se posvjedočilo da izrečena kazna izopćenja nije bila samo stvar jednoga biskupa i njegova rivalstva, određeno je upravo to da se sve skupa rješava na sinodama. Kanon 6. Nicejskoga sabora govori o prednosti nekih biskupa i o nemogućnosti da netko bude zaređen za biskupa bez suglasnosti metropolita. Biskupi Aleksandrije, Antiohije i Rima imaju povlastice, što svjedoči da je politički model utjecao i na takvu organizaciju Crkve. Postojala je praksa, kanon 7., da je neke sinode otvarao jeruzalemski biskup jer je još uvijek bila jaka svijest kako je Jeruzalem majka crkava. Davanje i očuvanje dostojanstva određenih metropola značilo je distanciranje od židovske tradicije.

Svi ti kanoni označavaju kanonsku potvrdu biskupske službe te međusobne odnose unutar pojedinih metroplolija ili crkava. U središtu su svakako biskupi koji su nositelji života crkava. Crkveno zakonodavstvo kasnije će biti još preciznije obznanjeno preko sinodalnih akata (sinodsko pravo). Još preciznije o biskupskoj službi govorili su propisi ili kanoni doneseni na Kalcedonskom saboru 451. godine, kada je između ostaloga određeno: osuđuju se svi koji novcem kupuju crkvenu službu (kan. 2.), putujući biskupi podložni su kanonskom pravu (kan. 5.), klerici u ubožnicama, manastirima i svetištima podložni su biskupovoj vlasti (kan. 8.), ograničava se mogućnost da se biskupa optuži pred sudom (kan. 9.), ni jedna se crkvena pokrajina ne može dijeliti da se osnuje nova Crkva (kan. 12.), zabranjuje se otuđivanje vlasništva umrloga biskupa (kan. 22.), odlučuje se da nakon smrti biskupa novi biskup mora biti imenovan unutar tri mjeseca (kan. 25.), odlučuje se da carigradski patrijarh ima istu čast kao i rimski jer je Carigrad $\gg$ Novi Rim «. Izaslanici rimskoga biskupa nisu bili nazočni pri izglasavanju toga kanona, pa je uslijedilo protivljenje (kan. 28.), zabranjuje se degradacija biskupa 
na razinu prezbitera, nego se samo uz dozvolu može svrgnuti (kan. 29.) ${ }^{40}$ Svakako, to je nešto novo u Crkvi.

Uz navedene propise dobro je istaknuti da je bila vrlo raširena ideja ženidbe biskupa s crkvenom zajednicom. A pojava koepiskopa ili biskupa za selo bila je izvan prakse ili barem vrlo rijetka.

\section{Prezbiter u naravi Crkve}

Koliko god Crkva uočavala važnost biskupske službe u ostvarivanju Kristova naloga, uviđa potrebu važnosti svećeničke i đakonske službe. Oni su biskupovi suradnici koji okupljaju zajednicu, ali u toj zajednici imaju dio vlasti, dok potpuna vlast naučavanja, upravljanja i posvećivanja pripada biskupu.

\subsection{Prezbiterska služba u Zajednici}

Iz prethodnoga govora o biskupima indirektno se može dobiti uvid i u problematiku razvoja prezbiterske službe. ${ }^{41} \mathrm{U}$ nekoliko napomena, stečenih na temelju pisane ostavštine crkvenih otaca, uočava se položaj svećenika prezbitera u odnosu prema biskupu. Vidljivo je gdje je sa svojim djelovanjem i nastupima do izražaja došao biskup, bilo na crkvenom ili civilnom području, tu je manje dolazio do izražaja prezbiter. No jedan nije isključivao drugoga, moglo bi se reći da je u crkvenoj hijerarhiji već na samom početku postojalo načelo supsidijarnosti. ${ }^{42}$ Unatoč tomu ipak je prezbiter imao svoje mjesto u hijerarhijskoj strukturi Crkve.

Prezbiteri su u hijerarhijskoj strukturi činili biskupov senat ili, jednostavno, prezbiterij. Svoj oblik preuzeo je od grčko-rimske uprave, a izjednačen je s apostolskim kolegijem. Oni su bili biskupovi savjetnici koji su svojim savjetima pomagali biskupu u vođenju zajednice i surađivali su u liturgijskim slavljima: $u$ krštenju, u euharistijskom slavlju, u pomirenju penitenata, u ređenju prezbitera. Do izražaja je došlo upravo svećeničko obilježje o uskoj suradnji s biskupom. U to vrijeme ne samo da je došla do izražaja svećenička kolegijalnost $s$ biskupom nego je i među svim službenicima u Crkvi vladala kršćanska kolegijalnost. Aspekt kolegijalnosti među crkvenim službenicima doživljavao je svoju slabiju stranu u ponekim situacijama:

\footnotetext{
${ }^{40}$ Usp. https://hr.wikipedia.org/wiki/Kalcedonski_sabor (11.6. 2018.)

${ }^{41}$ O službi prezbitera upućujemo na: A. REBIĆ, Pojam i služba svećenika u Svetom pismu Staroga i Novoga zavjeta, u: Bogoslovska smotra 41(1971.)1, 23-43.; I. ŠPORČIĆ, Biblijsko poimanje služenja i crkvenost službâ, u: Bogoslovska smotra 72(2002.)2-3, 277-308.; A. ŠKVORČEVIĆ, Prezbiterat u svjetlu ranokršćanske tradicije i II. Vatikanskog sabora, u: Kateheza 5(1983.)2, 5-17.

${ }^{42} \mathrm{O}$ načelu supsidijarnosti i načelu služenja upućujemo na: M. CIFRAK, Načelo supsidijarnosti u Novom Zavjetu, u: Bogoslovska smotra 79(2009.)1, 165-182.; I. KARLIĆ, Kristologija služenja: Kristološko utemeljenje kršćanskog služenja, u: Bogoslovska smotra 78(2008.)3, 533-558.
} 
to je vrijeme progona, vrijeme odsutnosti biskupa, zatim u trenutcima kada se kršćanstvo počelo širiti i izvan gradova te za vrijeme umnažanja mjesta za kult, kao što su župne crkve u gradovima i selima, posebno je bio u pitanju kult mučenika.

Već je u trećem stoljeću dopušteno svećenicima slaviti euharistiju, krštavati, pomirivati penitente, uz biskupovo dopuštenje. Te ovlasti s vremenom postaju redovne za prezbitera, posebno u onim mjestima gdje je biskup bio odsutan. Razvoj svećeničke službe takve naravi ipak nije bio ujednačen, a to je ovisilo o broju nazočnih biskupa u tom području: u Africi ili u središnjoj Italiji, upravo zbog dovoljnoga broja biskupa, svećenicima nije omogućen prostor apostolskoga individualnoga djelovanja. U Galiji i sjevernoj Italiji svećenici su imali veću autonomiju i obavljali su vjersku službu ondje gdje je bilo potrebno. Na Istoku, posebno u Egiptu, postojao je putujući svećenik koji je posjećivao područja koja su ostala bez redovnoga svećenika i imao je ulogu zamjene koepiskopa.

Arhiprezbiter, najstariji svećenik, pojavljuje se u četvrtom stoljeću u katedralnim crkvama. Zamjenjuje odsutnoga biskupa, nadzire kler i poučava druge administrativne funkcije. To je svećenik koji je bio na selu i koji je vodio brigu o drugim svećenicima. ${ }^{43}$

$S$ vremenom se svećenicima sve više povjeravalo propovijedanje riječi Božje, što je bilo izričito povjereno biskupu kojemu je pripadala ta čast, dužnost i zaslužni čin. $\mathrm{Na}$ Istoku je postojala praksa propovijedanja prezbitera, a o tome svjedoči i Egerija dok opisuje nedjeljno jutarnje bogoslužje: »Ali ovdje je takav običaj da između svećenika što sjede propovijedaju koji žele, a biskup propovijeda poslije njih svih. ${ }^{44} \mathrm{Na} \mathrm{Za-}$ padu je praksa da prezbiter propovijeda vrlo sporo tekla, što posebno sveti Jeronim na svoj poseban način kritizira dok piše svoju poslanicu svećeniku Nepocijanu. ${ }^{45} \mathrm{U}$ Africi je Augustin prvi koji je kao prezbiter propovijedao javno i u crkvi. ${ }^{46}$

U prvo doba Crkve postojala je razlika između klera i naroda. O tome svjedoče Klementovo pismo ${ }^{47}$ i poslanice Ignacija Antiohijskoga. ${ }^{48} \mathrm{U}$ prvoj polovici treće-

\footnotetext{
${ }^{43}$ Usp. V. GROSSI, A. BERARDINO, La Chiesa antica: ecclesiologia e istituzioni, Roma, 1984., 77-120. $\mathrm{Za}$ tu temu korisno je vidjeti druge izvore: B. GOLUŽA, Povijest Crkve, Mostar, 1998., 55-60.; B. TESTA, Sakramenti Crkve, Zagreb, 2009., 211-269.

${ }^{44}$ EGERIJA, Putopis, 25, 1, M. Mandac (ur.), Makarska, 1999.

${ }^{45}$ Vidi bilješku br. 36.

${ }^{46}$ Usp. POSSIDIO, Vita di Agostino, br. 7, 1.

${ }^{47}$ Usp. Klementovo pismo Korinćanima, br. 40, 1, u: Apostolski oci II. Klement govori o posebnim zaduženjima svećenika i laika.

${ }^{48}$ Usp. IGNACIJE ANTIOHIJSKI, Pismo Filadelfijanima, br. 1, 1; 4; ISTI, Pismo Smirnjanima, br. 8,1 .
} 
ga stoljeća u rimskoj Crkvi kojoj je predsjedao Kornelije bilo je već mnogo nižih redova: »Zar, dakle, taj osvetnik evanđelja (Novacijan) nije znao da u katoličkoj Crkvi smije biti jedan biskup? U ovoj Crkvi - znao je, kako ne - ima: četrdeset $\mathrm{i}$ šest svećenika, sedam đakona, sedam podđakona, četrdeset i dva akolita, pedeset $\mathrm{i}$ dva egzorcista i vratara, a više od petnaest stotina udovica i potrebnih. Te sve hrani Gospodnja milost i čovjekoljublje. $\ll{ }^{49}$

Kler je uživao društveni ugled. Civilni zakon povećavao je povlastice: oslobađanje od takse, isključivanje iz ropstva. Klerici su pribrojavani među izabrane, a oni su bili branitelji države.

\subsection{FORMACIJA CRKVENIH SLUŽBENIKA}

Formacija klera odvijala se u župama. Od petoga stoljeća pa nadalje neki manastiri, kao što je bio u Lerinsu, postali su sjemeništa za sve biskupe. Zahtijevao se skroman život; na Istoku u drugoj polovici četvrtoga stoljeća javlja se tonzura. Za dobro poznavanje Svetoga pisma Augustin potiče da se crkveni službenici bave potrebnim znanjima stečenim iz društvenih znanosti. Kršćani i kršćanski učitelji moraju posjedovati znanje i umijeće govora koje se stječe određenim vježbama, onako kako ih stječu poganski učitelji. »Mladima koji su željni znanja, obdareni inteligencijom i bogobojažljivi koji traže znanja mogu se dati ovi zdravi savjeti: neka se ne dopusti da mirnoga duha slijede ijednu znanost koja se nalazi izvan Crkve Kristove, nego da ih vrednuju mudroga duha i s marljivošću. Može se dogoditi da naiđu na učenosti koje su ljudi izmislili, a te učenosti su različite od onoga kako ih je želio sam Izumitelj i koje su pale u zaborav radi sumnje da bi mogle pobuditi interes onoga koji je u zabludi ili mogu naići na slučajeve u kojima te učenosti sadrže društvo udruženo s demonima kao po nekom ugovoru i dogovoru utemeljen na nekim znakovima. $U$ ovakvim slučajevima naši mladi moraju ih odlučno odbaciti i gnušati se na njih. I nadalje, moraju biti nezainteresirani za suvišne i raskalašene znanosti. Naime, što se tiče humanih institucija koje služe društvenom suživotu, radi odnosa koje imaju sa sadašnjim životom, njih ne smiju zanemariti. Recimo sada samo jednu riječ o drugim znanostima koje pronalazimo kod pogana. One imaju pozitivan opis predmeta, prošlih i sadašnjih, koji se tiču osjetila tijela. Njima treba nadodati eksperimente i pretpostavke s područja fizike. Pozitivna je uporaba metode rasuđivanja. Izvan ovih vjerujem da ne postoje druge koje su korisne. $\ll^{50}$

Navedeni citat upozorava svakoga kršćanina koji se želi baviti znanošću da on sam mora biti dobro poučen kako bi mogao prosuditi koja je dobra, a koja loša znanost.

\footnotetext{
${ }^{49}$ EUZEBIJE CEZAREJSKI, Crkvena povijest, 6, 43, 11.

${ }^{50}$ SANT'AGOSTINO, La dottrina cristiana, 2, 39, 58, Roma, 1992.
} 
A ono što je dobro, makar bilo i kod pogana, a da je korisno za kršćanski nauk, treba preuzeti. U spomenutom djelu koje govori o kršćanskom nauku mogu se pronaći i druge Augustinove pouke i preporuke po pitanju stjecanja intelektualnoga znanja. Tako spominje da je potrebno poznavati osim latinskoga jezika i grčki, hebrejski, povijest, astronomiju i astrologiju, dijalektiku, zatim steći poznavanje filozofije i klasične kulture, a ponajviše radi propovijedanja kršćanski učitelji trebaju poznavati umjetnost retorike koja je potrebna radi obrane istine.

Posebna zadaća biskupa bila je poučavanje, a da bi mogao poučavati on sam mora studirati. Katkada su bile potrebe da je morao naučavati i više od onoga što je naučio, ako ne to, onda je u najboljem slučaju morao istovremeno poučavati druge $i$ sam studirati. U takvoj se situaciji našao Ambrozije koji je na čudesan i nenadan način izabran za biskupa. Bio je nespreman za službu biskupa, a sam o sebi govori: $\gg$ Ne prisvajam si slavu apostola, niti dar proroka, ni krepost evanđelista, ni mudrost pastira. Želja mi je samo postići marljivost u studiranju Svetoga Pisma. A meni se ni to nije dogodilo. Iščupan iz sudišta i sudske vlasti i izabran sam za biskupa, počeo sam poučavati ono što nisam sam naučio. Dogodilo se, dakle, da poučavam prije nego sam naučio. Moram dakle istodobno učiti i poučavati, jer prije ovoga manjkalo mi je vremena za učenje. $\ll^{51}$

Ambrozije je zahvaćen potrebom poučavanja drugih i sebe samoga. Službeno postavljeni pred narod, svećenik i biskup dužni su prenositi darove Božje razlivene po Duhu Svetome. Mnoštvo primjera koji su se trebali spremati intelektualno i duhovno za kraljevsku, proročku i svećeničku službu Ambrozije stavlja pred oči, poput kralja Davida, učitelja poniznosti i skromnosti. Nema toga svećenika ni biskupa koji ne mora poučavati i biti poučavan jer samo je jedan Učitelj koji nije morao prethodno učiti da bi druge učio. Uz Augustina i Ambrozija posebno se još ističu u intelektualnom odgoju klerika Jeronim, Ivan Zlatousti, Teodoret Cirski, Leon Veliki. $^{52}$

U nekoliko riječi moglo bi se reći u čemu i za što je klerik trebao imati formaciju. Onaj tko se prihvati crkvene službe morao je steći određenu metodiku u poučavanju, imati sposobnost upravljanja materijalnim dobrima koje mu je zajednica povjerila, donoseći ih pred oltar, snagom svojega duha trebao je izlijevati darove Duha Svetoga, posebno kroz karizme. Nisu se uvijek izbjegle zamke i zlouporabe koje su se krile u prihvaćanju službe.

\footnotetext{
${ }^{51}$ SANT' AMBROGIO, I doveri, I, 4.

${ }^{52}$ Poneka misao o potrebi poučavanja biskupa i svećenika kod crkvenih Otaca može se pronaći u članku: D. TUKARA, Dijaloška uloga svećenika kod Otaca, u: Vjesnik Đakovačko-osječke nadbiskupije i Srijemske biskupije 138(2010.)3-4, 168-172.
} 


\subsection{Celibat I UZdRŽLjIVOsT OD ŽEnIDbe}

Članovi klera, biskupi, prezbiteri i đakoni morali su imati najuzvišeniji ideal pred sobom kako bi i sami drugima postali primjer života odijeljenoga od svjetskih sadržaja. Dobivši zadaću posvećivanja drugih, pozvani su sami na sveti život. Od samih početaka bili su obvezni zadovoljiti određene moralne kriterije koji su ih činili drukčijima od ostalih kršćana.

Celibat u samim početcima Crkve nije bio naložen kleru, a oženjeni nisu preuzimali obvezu bračne uzdržljivosti. Ubrzo je na snagu stupilo pravilo da se kler, to jest biskupi, prezbiteri i đakoni, ne mogu ženiti nakon što su zaređeni, osim da se vrate u laičko stanje. Donesena regula uključivala je shvaćanje da je uzdržljivost od ženidbe iznad same ženidbe i da je uzdržljivost prikladna za službenike Božje, a to je vodilo prema ideji svećenika celepsa. Budući da je veliki broj kršćana svojom voljom živio u stanju beženstva, što je bilo ugodno Bogu, bilo je stoga normalno da se među njima nađu i klerici. Takav je način života bio proširen, pa je došlo do njegova ozakonjenja. Treba reći da celibat nije u početku postavljen isključivim zakonom za cijelu Crkvu, on je bio krajevnoga značenja, za španjolsku Crkvu. No ubrzo će steći status univerzalnosti. ${ }^{53}$

Prevladava mišljenje da je celibat bio raširen u prvoj Crkvi. Na Istoku su propisi bili manje strogi: tko se oženi prije ređenja, mogao je obnašati svećeničku službu. Na Zapadu vrlo brzo susrećemo obvezu uzdržljivosti za oženjene klerike. Koncil u Anciri 314. godine (kan. 10.) dopušta ženidbu đakonu celepsu samo ako se prije ređenja izjasnio da želi ženidbu. Sinoda u Elviri (oko 303. godine, kan. 33.) kaže da članovi višega klera oženjeni prije ređenja moraju održavati uzdržljivost. U rimskoj Crkvi apsolutna uzdržljivost traži se od svih oženjenih svećenika. Dekretali pape Siricija i Inocenta proširuju pravilo Elvire na cijeli Zapad prema kraju četvrtoga stoljeća, a kasnije su ga preuzeli i drugi koncili.

Uglavnom, kandidat za crkvenu službu morao se odlučiti ili za ženidbu ili za uzdržljivost od ženidbe. Koncil u Kartagi 390. godine (kan. 2.) propisuje potpunu uzdržljivost za oženjene svećenike. U razmaku od nekoliko godina održavali su se koncili koji su ponavljali te propise, no to samo navodi na sumnju u uspješnost održavanja tih propisa. Leon Veliki uveo je obvezu celibata i za subđakone.

${ }^{53}$ Usp. J. ZEILLER, Organizzazione ecclesiastica, u: Storia della Chiesa. Dalla fine del II secolo alla pace costantiniana, Milano, 1995., 551-573. Po pitanju uzdržljivosti od ženidbe piše: B. DUDA, Ženidba i djevičanstvo u 1 Kor 7, u: Bogoslovska smotra 49(1979.)1-2, 20-51.; M. ŠKVORC, Svećenici i celibat, u: Kateheza 5(1983.)2, 49-52. 


\section{Zaključak}

Držimo da smo se pozabavili sa širokom i važnom temom pišući o razvoju biskupske i prezbiterske službe u prvim stoljećima Crkve.

Tema je široka jer po svome sadržaju i naravi zahtijeva govor o Crkvi. Jedna i jedina Crkva Kristova izgrađena je od mnogih pojedinačnih Crkava, a svaka od njih imala je poseban odnos prema rimskoj Crkvi. Svaka od tih Crkava bila je u zajedništvu Riječi Božje i Tijela Kristova. Crkva je već tada imala i svoju strukturu o kojoj svjedoče crkveni oci, ali i dobru međusobnu komunikaciju.

Struktura Crkve zahtijeva i govor o službenicima, a govor o crkvenim strukturama uvijek je važan zadatak teologije. Do izražaja su došli biskupi i prezbiteri, čije se postojanje dovodi u vezu s Kristovom željom i zapovijedi o njihovu ustanovljenju, nasljeđivanju i poslanju. Uvijek su crkveni oci naglašavali međusobnu ovisnost Krista i crkvenih službenika, međusobnu ovisnost biskupa i prezbitera te hijerarhije, općenito, s vjernicima. Otačka literarna baština svjedoči o monarhijskom ustrojstvu Crkve, unutar kojega dolazi do izražaja biskupski kolegijalitet i svaki pojedini biskup. Zajedništvo biskupa za crkvene oce bilo je jamstvo očuvanja istine i jedinstva. U djelovanju pojedinoga biskupa do izražaja je došla njegova sloboda, ali sloboda koja je u bitnim pitanjima vjere uključivala potrebu traženja jednodušnosti svih biskupa. Solidarnost i supsidijarnost unutar univerzalne Crkve artikulirana je kod prezbiterske službe, ali opet s naglaskom na određenu samostalnost u liturgijskom i katehetskom djelovanju. Treba naglasiti da je u cijeloj strukturi Crkve od otaca do danas bilo određenoga razvoja, posebno po pitanju terminologije za crkvene službenike, ali nikada u bitnome. 


\title{
THE DEVELOPMENT OF THE OFFICE OF BISHOP AND PRESBYTER IN THE FIRST CENTURIES OF THE CHURCH
}

\author{
Drago TUKARA*
}

Summary: The article implicitly addresses the Church as an institution and organization, while it directly and more explicitly presents those that make a part of Church hierarchy, bishops and presbyteries. To better present and understand the existence and mission of bishops and presbyters, it was necessary, at least briefly, to highlight the very nature of the Church. The author divides the article in three chapters. In the first chapter, he represents the Church that has had its roots in the Old Testament and found its fullness and foundations in the Person of Jesus Christ. She has been present in God's plan since the Old Testament times when the prophets announced her in images. In the second chapter, the author discusses the office of bishops in the early Church. This part addresses what the Church Fathers said about bishops, and their role and place within the early Church, and how particular councils and synods have defined them. The author brings the Church Fathers' personal reflections and understanding of the office of bishop as well as certain canons that have emerged as the fruit of bishop's collegiality and unity. The third chapter talks about presbyters. The author first presents the role of presbyter in the early Church, and then indicates the developmental path from terminology itself to the area of action at particular times in the life of the Church. The presbyter is put in a co-relationship with the bishop, he is dependent on him, but in time, due to new circumstances, he has gained a certain autonomy within the community. The author also emphasizes the importance of formation and education of church officials in areas of theology and morals.

Keywords: Church, bishop, presbyter, hierarchy, church community.

* Asst. Prof. Drago Tukara, Ph. D., Catholic Faculty of Theology, J. J. Strossmayer University of Osijek, P. Preradovića 17, 31400 Đakovo, Croatia, drago.tukara@gmail.com 